\title{
Response of Seedling Roughstalk Bluegrass and Creeping Bentgrass to Bispyribac-sodium or Sulfosulfuron
}

James M. Rutledge ${ }^{1,4}$, Daniel V. Weisenberger², and Zachary J. Reicher ${ }^{3}$ Purdue University, Department of Agronomy, Lilly Hall of Life Science, 915 West State Street West Lafayette, IN 47907-2054

Additional index words. Poa trivialis, certainty, velocity, seedling

Abstract. Controlling mature roughstalk bluegrass (Poa trivialis L.; RSBG) using bispyribac-sodium (BYS) or sulfosulfuron (SUL) often yields inconsistent results. Attempting to control RSBG shortly after emergence may eliminate or reduce it with fewer inputs and less noticeable creeping bentgrass (Agrostis stolonifera L.; CBG) phytotoxicity than if treated at maturity. The objective of these studies was to determine whether BYS or SUL controls seedling RSBG with only minimal seedling CBG cover reduction. Four separate studies on either CBG or RSBG were conducted in spring or fall of 2007 and repeated in $\mathbf{2 0 0 8}$ to simulate spring or fall fairway establishment. Studies were arranged as split plots with application timing $(7,14,21$, or 28 days after CBG emergence) as main plots and subplots were herbicide treatments in a $2 \times 5$ factorial with BYS or SUL applied once at five uniformly increasing rates of $0,18,37,55$, and $74 \mathrm{~g} \cdot \mathrm{ha}^{-1}$ a.i. and 0,6 , 13, 19, and $26 \mathrm{~g} \cdot \mathrm{ha}^{-1}$ a.i., respectively. Plots were maintained at $1.3 \mathrm{~cm}$ and emergence was defined as $\approx \mathbf{5 0} \%$ of the study area being populated with one- to two-leaf CBG seedlings. Spring-seeded stands of CBG were safely treated with BYS 14 or more days after emergence (DAE) at $55 \mathrm{~g} \cdot \mathrm{ha}^{-1}$ a.i. or less, whereas SUL was not safe by 28 DAE at any tested rate. Fall-seeded CBG was generally less sensitive to BYS and SUL. Sulfosulfuron resulted in excessive damage if applied to seedling CBG before $14 \mathrm{DAE}$ at rates greater than $6 \mathrm{~g} \cdot \mathrm{ha}^{-1}$ a.i. and if applied before $21 \mathrm{DAE}$ at rates greater than $26 \mathrm{~g} \cdot \mathrm{ha}^{-1}$. Bispyribacsodium was safely applied as soon as 7 DAE at rates of $74 \mathrm{~g} \cdot \mathrm{ha}^{-1}$ a.i. or less. Chemical names used: $\{2,6$-bis[(4,6-dimethoxypyrimidin-2-yl)oxy] benzoic acid\} (bispyribacsodium); \{1-[4,6-dimethoxypyrimidin-2-yl]-3-[2-ethanesulfonyl-imidazo(1,2-a)pyridine3-yl) sulfonyl]urea $\}$ (sulfosulfuron).

Roughstalk bluegrass (Poa trivialis L.; RSBG) is a problematic weed throughout much of the northeastern quarter of the United States. Roughstalk bluegrass performs poorly under summer stresses, including high temperature, drought, and disease pressure (Hurley and Funk, 1985; Sifers and Beard, 1993). The result is chlorotic, thinning turf, often resulting in significant stand loss by late summer in severe years. Roughstalk bluegrass can be introduced into managed turf stands by spread from naturalized populations in the vicinity or through contaminated seed lots (Hurley and Funk, 1985; Levy, 1998).

Roughstalk bluegrass was first introduced to North America in the 1600s from Europe and has since become naturalized throughout much of its range of adaptability. Once introduced, RSBG seed can persist and remain viable in soil for 5 years and can germinate in as little as $7 \mathrm{~d}$ at temperatures ranging from 6 to $30{ }^{\circ} \mathrm{C}$ (Grime et al., 1981; Milton, 1936). Once established, RSBG rapidly spreads vegetatively by stolons that can be transported

\footnotetext{
Received for publication 29 Sept. 2009. Accepted for publication 16 Nov. 2009.

${ }^{1}$ Graduate Research Assistant.

${ }^{2}$ Research Agronomist.

${ }^{3}$ Professor.

${ }^{4}$ To whom reprint requests should be addressed; e-mailjrutledg@purdue.edu.
}

throughout the stand by routine management practices such as aerification. The result is seed-producing plants that are well-adapted to conditions of managed turf systems in the northeastern quarter of the United States, except when high temperatures arrive in summer (Hurley, 1983).

Roughstalk bluegrass is also a persistent weed in grass seed production fields of the Pacific Northwest. From 1990 to 1996, grass seed producers were subjected to a mandatory transition from open-field burning to mechanical removal of postharvest residues in western Oregon (Mueller-Warrant, 1990; MuellerWarrant and Rosato, 2005). Roughstalk bluegrass was primarily controlled in seed fields by burning, but currently RSBG must be controlled using herbicides to minimize seed contamination and to allow the desirable stand to remain productive (Mueller-Warrant, 1990; Mueller-Warrant and Rosato, 2005). Soon after burn restrictions were imposed, Levy (1998) conducted a seed survey and found that $30 \%$ of creeping bentgrass (Agrostis stolonifera L.; CBG) seed lots tested contained RSBG. This study validated concern for the introduction of RSBG into $\mathrm{CBG}$ fairways through contaminated $\mathrm{CBG}$ seed lots. However, the incidence of contamination has potentially decreased in recent years because of increased awareness and improved sanitation by seed producers. Regardless of contami- nation source, RSBG commonly germinates and establishes simultaneously with the desired species in newly seeded turf stands.

Options to control mature RSBG in CBG are limited. Nonselective removal using glyphosate is effective but undesirable as a result of $\mathrm{CBG}$ cover reduction. Selective control of RSBG in CBG is effective using bispyribac-sodium (BYS) \{2,6-bis[(4,6-dimethoxypyrimidin-2-yl)oxy] benzoic acid $\}$ or sulfosulfuron(SUL) \{1-[4,6-dimethoxypyrimidin-2-yl]-3-[2-ethanesulfonyl-imidazo(1,2a)pyridine-3-yl)sulfonyl] \} (Anonymous, 2004, 2005; Morton et al., 2007; Riego et al., 2005). However, controlling mature RSBG typically requires multiple applications over multiple years of either herbicide and causes short-term CBG phytotoxicity (Morton et al., 2007). Both herbicides are also highly dependent on warm temperatures (generally 20 to $25^{\circ} \mathrm{C}$ ) to both achieve RSBG control and minimize CBG damage (Anonymous, 2004; McCullough and Hart, 2006a, 2006b, 2008). In a 2-year study conducted in Virginia, three applications of BYS at $37 \mathrm{~g} \cdot \mathrm{ha}^{-1}$ a.i. starting in June, August, or September reduced RSBG 10 weeks after initial treatment by $88 \%, 48 \%$, and $11 \%$, respectively (Askew et al., 2004). Therefore, BYS applications are recommended to be made between 15 Apr. and 1 Sept. and SUL applications between 15 June and 1 Sept. (Anonymous, 2004, 2005).

Controlling RSBG soon after emergence in a newly seeded stand could reduce or eliminate it in the mature stand, but CBG safety must be confirmed. Dernoeden et al. (2008) reported that BYS applied in Maryland on CBG at 25, 49, or $74 \mathrm{~g} \cdot \mathrm{ha}^{-1}$ a.i. 2 and 4 weeks after emergence did not result in significant cover reduction 9 weeks after the initial application. However, no BYS treatments were safe on seedling CBG at the Connecticut site in the same report. Early applications of SUL on CBG may result in cover loss as well. Our earlier work showed the effect of SUL applied at 13,26 , or $56 \mathrm{~g} \cdot \mathrm{ha}^{-1}$ a.i. 1, 2, 3, or 4 weeks after seeding creeping bentgrass (Rutledge et al., 2009). We found that SUL applied 4 weeks after seeding at $13 \mathrm{~g} \cdot \mathrm{ha}^{-1}$ a.i. was the only treatment that did not reduce $\mathrm{CBG}$ cover by 8 weeks after seeding. However, control of seedling RSBG with SUL at rates lower than $13 \mathrm{~g} \cdot \mathrm{ha}^{-1}$ a.i. may be feasible. Additionally, evaluation of BYS rates and application timings may allow its use to control seedling RSBG in seedling CBG. Controlling RSBG soon after seeding might be the most effective and efficient method for long-term control. Therefore, our objective was to determine whether BYS or SUL controls seedling RSBG with minimal seedling CBG cover reduction.

\section{Materials and Methods}

Four separate studies on either CBG or RSBG were conducted in spring or fall of 2007 and repeated in 2008 to simulate spring or fall fairway establishment. Studies were conducted in West Lafayette, IN, at the W.H. Daniel Research and Diagnostic Center on a Stark silt loam (fine-silty mixed mesic Aeric Ochraqualf) with $\mathrm{pH}$ of 7.2 and $3.8 \%$ 
Table 1. Herbicide application, seeding, and germination dates for creeping bentgrass and roughstalk bluegrass seeded in 2007 and 2008.

\begin{tabular}{|c|c|c|c|c|}
\hline & \multicolumn{2}{|c|}{2007} & \multicolumn{2}{|c|}{2008} \\
\hline & Spring & Fall & Spring & Fall \\
\hline \multicolumn{5}{|c|}{ Seeding date } \\
\hline $1 \mathrm{WAE}^{\mathrm{z}}$ & 7 May & 1 Aug. & 13 May & $11 \mathrm{Aug}$. \\
\hline $2 \mathrm{WAE}$ & 28 Apr. & 1 Aug. & 5 May & 11 Aug. \\
\hline 3 WAE & 21 Apr. & 1 Aug. & 29 Apr. & 11 Aug. \\
\hline $4 \mathrm{WAE}$ & 10 Apr. & 1 Aug. & 17 Apr. & 11 Aug. \\
\hline \multicolumn{5}{|c|}{ Germination date } \\
\hline $1 \mathrm{WAE}$ & 14 May & 9 Aug. & 21 May & 19 Aug. \\
\hline $2 \mathrm{WAE}$ & 7 May & 9 Aug. & 13 May & 19 Aug. \\
\hline 3 WAE & 28 Apr. & 9 Aug. & 5 May & 19 Aug. \\
\hline $4 \mathrm{WAE}$ & 20 Apr. & 9 Aug. & 28 Apr. & 19 Aug. \\
\hline \multicolumn{5}{|c|}{ Application timing } \\
\hline $1 \mathrm{WAE}$ & 23 May & 16 Aug. & 29 May & $26 \mathrm{Aug}$. \\
\hline $2 \mathrm{WAE}$ & 23 May & 23 Aug. & 29 May & 2 Sept. \\
\hline $3 \mathrm{WAE}$ & 23 May & 29 Aug. & 29 May & 9 Sept. \\
\hline $4 \mathrm{WAE}$ & 23 May & 5 Sept. & 29 May & 16 Sept. \\
\hline
\end{tabular}

organic matter. The area was treated 4 and 6 weeks before initiation of each study with glyphosate (1100 g.ha ${ }^{-1}$ a.i.) to kill existing CBG cover. The seedbed was prepared by cultivating the surface $1 \mathrm{~cm}$ with an enginedriven power rake (Slice-N-Rake; Turfco Mfg. Inc., Minneapolis, MN) followed by drop seeding in two directions. Separate but adjacent studies were seeded with 'L93' CBG or 'Laser' RSBG at 36.6 or $114.4 \mathrm{~kg}$ pure live seed/ha, respectively. 'L93' was chosen because of its common use on golf course fairways and 'Laser' was selected as a vigorous RSBG variety from previous studies (Morton et al., 2009). Starter fertilizer $(6 \mathrm{~N}-10.5 \mathrm{P}-1.9 \mathrm{~K})$ was applied at $32 \mathrm{~kg}$ phosphorus/ha and lightweight germination blankets $(0.5 \mathrm{oz}$ Germination \& Insect Blanket; AM Leonard, Piqua, $\mathrm{OH}$ ) were placed over the plots for 1 week after seeding. Plots were lightly irrigated twice daily to ensure a moist seedbed until germination, after which plots were irrigated to prevent drought stress. Emergence was defined as $\approx 50 \%$ of the $\mathrm{CBG}$ study area being populated with one to two leaf seedlings. Plots were mowed with a reel mower at $1.25 \mathrm{~cm}$ three times per week with clippings returned to simulate typical golf course fairway management practices. Studies were arranged as split plots with application timing $(7,14$, 21 , or $28 \mathrm{~d}$ after CBG emergence) as main plots and subplots were herbicide treatments in a $2 \times 5$ factorial with BYS (17.6 SP) or SUL (75 WDG) applied once at five uniformly increasing rates of $0,18,37,55$, and $74 \mathrm{~g} \cdot \mathrm{ha}^{-1}$ a.i. and $0,6,13,19$, and $26 \mathrm{~g} \cdot \mathrm{ha}^{-1}$ a.i., respectively. All SUL applications included $0.25 \% \mathrm{v} / \mathrm{v}$ nonionic surfactant (MON 0818). The highest labeled rate for RSBG control in $\mathrm{CBG}$ for each product was selected as the highest rate in the studies and then $0 \times, 0.25 \times$, $0.5 \times$, and $0.75 \times$ rates were calculated (Anonymous, 2004, 2005). Subplots were $1.0 \times 1.0 \mathrm{~m}$ with $0.3-\mathrm{m}$ borders separating main plots and were replicated three times. Herbicides were applied using a handheld two-nozzle boom (TeeJet XR8001VS; Spraying Systems Co., Wheaton, IL) at $240 \mathrm{kPa}$ in $800 \mathrm{~L} \cdot \mathrm{ha}^{-1}$.

Phytotoxicity to $\mathrm{CBG}$ and percent cover of $\mathrm{CBG}$ and $\mathrm{RSBG}$ were visually rated

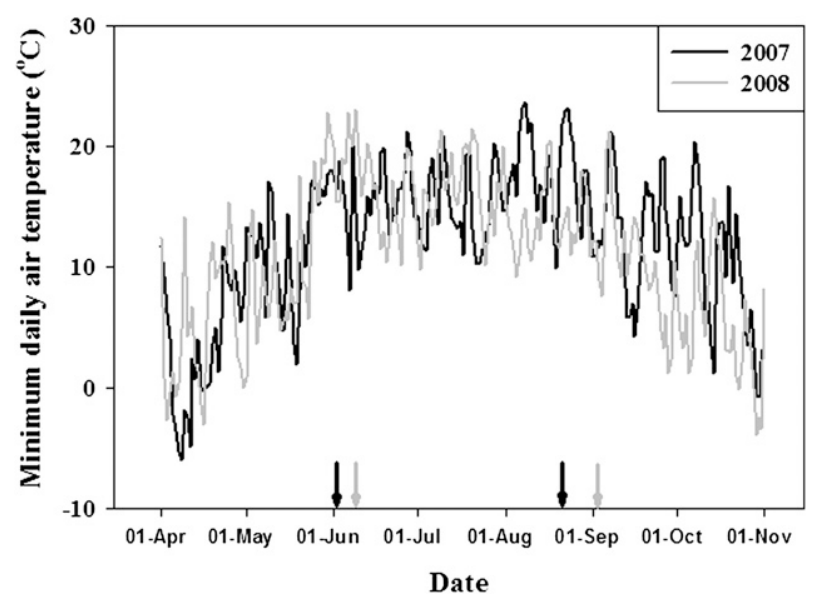

Fig. 1. Minimum daily air temperatures in West Lafayette, IN, from 1 Apr. to 1 Nov. 2007 and 2008. Arrows in the spring represent application dates and arrows in the fall represent seeding dates. Black and gray arrows are representative of 2007 and 2008 dates, respectively.

weekly beginning 1 week after herbicide application. Phytotoxicity was assessed on a scale of 1 to 9 in which $1=$ brown turf, $7=$ acceptable turf, and $9=$ no visible phytotoxicity. A $1.0 \times 1.0 \mathrm{~m}$ transect with 49 intersections was used to assess turf cover on the final rating date of each study from which percent cover was calculated on a scale ranging from $0 \%$ to $100 \%$, in which $0 \%=$ no turf cover and $100 \%=$ complete turf cover. Data were arcsine-transformed and analyzed using PROC MIXED (Version 9.1; SAS Institute, Cary, NC). Years were treated as random variables in the statistical models when error variances between years were homogeneous (Steel et al., 1997). Means were separated using individual $t$ test comparisons at $\alpha=0.05$.

Spring-seeded studies. Main plots in spring-seeded studies were seeded on four dates based on predicted germination to be $7 \mathrm{~d}$ apart (Table 1). This allowed for a single herbicide application date in the spring while taking into account variability in germination rates with warming spring weather. This approach was primarily selected to mimic actions of practitioners who would seed as early in the spring as weather permits. Additionally, this approach helps limit the variability associated with weekly BYS and SUL applications in spring as temperatures warm. Control of RSBG and safety to CBG improve as temperatures warm in late spring or early summer (McCullough and Hart, 2006a, 2006b, 2008) (Fig. 1). Percent cover assessed 4 weeks after treatment (WAT) using the $1.0 \times 1.0 \mathrm{~m}$ transect and phytotoxicity recorded 2 WAT are presented for spring-seeded studies.

Fall-seeded studies. Fall-seeded studies were seeded on a single date and herbicides were applied at 1 -week intervals beginning 1 week after emergence (WAE). This would be typical of practitioners who ideally seed at the optimum timing in early to mid-August in Indiana. Fall applications began in August and were completed by mid-September of 2007 and 2008 (Table 1). With warmer mean daily low temperatures than in spring-seeded
Table 2. Phytotoxicity of spring-seeded creeping bentgrass averaged across 2 years, 2 weeks after application of sulfosulfuron (SUL) or bispyribac-sodium (BYS) soon after seeding, averaged across 2007 and 2008.

\begin{tabular}{|c|c|c|}
\hline$\overline{\text { Rate }^{z}}$ & SUL & BYS \\
\hline & \multicolumn{2}{|c|}{ Phytotoxicity $^{y}$} \\
\hline 0 & $8.6 \mathrm{a}^{\mathrm{xu}}$ & $8.8 \mathrm{a}$ \\
\hline $0.25 \times$ & $5.1 \mathrm{~b}$ & $8.1 \mathrm{~b}$ \\
\hline $0.5 \times$ & $4.2 \mathrm{c}$ & $8.0 \mathrm{~b}$ \\
\hline $0.75 \times$ & $3.3 \mathrm{~cd}$ & $8.0 \mathrm{~b}$ \\
\hline $1.0 \times$ & $2.9 \mathrm{~d}$ & $7.3 \mathrm{c}$ \\
\hline \multicolumn{3}{|l|}{ ANOVA $^{v}$} \\
\hline Week after emergence (W) & \multicolumn{2}{|c|}{ ** } \\
\hline Herbicide $(\mathrm{H})$ & \multicolumn{2}{|c|}{ ** } \\
\hline $\mathrm{H} \times \mathrm{W}$ & \multicolumn{2}{|c|}{ NS } \\
\hline Rate (R) & \multicolumn{2}{|c|}{$* *$} \\
\hline $\mathrm{R} \times \mathrm{W}$ & \multicolumn{2}{|c|}{ NS } \\
\hline $\mathrm{R} \times \mathrm{H}$ & \multicolumn{2}{|c|}{$* *$} \\
\hline $\mathrm{R} \times \mathrm{H} \times \mathrm{W}$ & \multicolumn{2}{|c|}{ NS } \\
\hline
\end{tabular}

${ }^{\mathrm{z}}$ Rates applied were $0,18,37,55$, and $74 \mathrm{~g} \cdot \mathrm{ha}^{-1}$ a.i. and $0,6,13,19$, and $26 \mathrm{~g} \cdot \mathrm{ha}^{-1}$ a.i. for BYS and SUL, respectively. Sulfosulfuron treatments include $0.25 \%$ nonionic surfactant.

y Phytotoxicity was rated on a scale from 1 to 9 in which 1 = brown turf, $7=$ acceptable turf, and $9=$ no visible phytotoxicity and ratings were recorded 2 weeks after application on 5 June 2007 and 12 June 2008.

${ }^{x}$ Data were arcsine-transformed and means were averaged over three replications, four application timings, and 2 years. Back-transformed means are presented.

wMeans within a column followed by the same letter are not significantly different at $P \leq 0.05$. ${ }_{\mathrm{NS}}, *, * *$ Nonsignificant, significant at $P \leq 0.05$, and significant at $P \leq 0.01$, respectively.

ANOVA $=$ analysis of variance.

studies, herbicide variability across application dates was expected to be minimal (Fig. 1). Percent CBG and RSBG cover assessed 8 WAE using the $1.0 \times 1.0 \mathrm{~m}$ transect are presented in fall-seeded studies.

\section{Results and Discussion}

\section{Spring studies}

Creeping bentgrass. Error variances between years for both phytotoxicity and cover 
were homogenous and thus years were combined in the statistical analysis of this study. Phytotoxicity resulting from BYS was min-

imal and did not persist beyond 3 WAT nor fall below the acceptable level of 7.0 across all rates 2 WAT when averaged across

Table 3. Percent cover of spring-seeded creeping bentgrass (CBG) averaged across 2 years and roughstalk bluegrass (RSBG) in 2007 and 2008, 4 weeks after application of sulfosulfuron (SUL) or bispyribacsodium (BYS) soon after emergence.

\begin{tabular}{|c|c|c|c|c|c|c|}
\hline \multirow[b]{3}{*}{ Main effect } & & & \multicolumn{4}{|c|}{ RSBG } \\
\hline & \multicolumn{2}{|c|}{ CBG } & \multicolumn{2}{|c|}{2007} & \multicolumn{2}{|c|}{2008} \\
\hline & SUL & $\overline{B Y S}$ & $\overline{\text { SUL }}$ & $\overline{B Y S}$ & $\overline{\mathrm{SUL}}$ & BYS \\
\hline$\overline{\text { Rate }^{z}}$ & ------- & 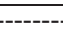 & --Per & ver $^{\mathrm{y}}=$ & $-\cdots$ & ------- \\
\hline 0 & $90 \mathrm{a}^{\mathrm{xw}}$ & $89 a$ & $83^{v}$ & 91 & $89 a^{v}$ & $84 \mathrm{a}$ \\
\hline $0.25 \times$ & $53 \mathrm{~b}$ & $92 \mathrm{a}$ & 15 & 45 & $14 \mathrm{~b}$ & $66 \mathrm{~b}$ \\
\hline $0.5 \times$ & $41 \mathrm{c}$ & $91 \mathrm{a}$ & 8 & 21 & $8 \mathrm{bc}$ & $36 \mathrm{c}$ \\
\hline $0.75 \times$ & $34 \mathrm{c}$ & $89 a$ & 4 & 11 & $3 \mathrm{~cd}$ & $28 \mathrm{~cd}$ \\
\hline $1.0 \times$ & $20 \mathrm{~d}$ & $80 \mathrm{~b}$ & 1 & 5 & $1 \mathrm{~d}$ & $21 \mathrm{~d}$ \\
\hline \multicolumn{7}{|l|}{ Application timing ${ }^{\mathrm{u}}$} \\
\hline $7 \mathrm{DAE}^{\mathrm{t}}$ & $12 b^{s}$ & $70 \mathrm{a}$ & $10^{\mathrm{r}}$ & 19 & $5 \mathrm{~b}^{\mathrm{r}}$ & $11 \mathrm{c}$ \\
\hline 14 DAE & $43 \mathrm{ab}$ & $88 \mathrm{a}$ & 15 & 30 & $10 \mathrm{~b}$ & $37 \mathrm{~b}$ \\
\hline $21 \mathrm{DAE}$ & $55 \mathrm{ab}$ & $93 \mathrm{a}$ & 9 & 18 & $19 \mathrm{~b}$ & $56 \mathrm{~b}$ \\
\hline $28 \mathrm{DAE}$ & $86 \mathrm{a}$ & $97 \mathrm{a}$ & 37 & 69 & $49 \mathrm{a}$ & $86 \mathrm{a}$ \\
\hline \multicolumn{7}{|l|}{ ANOVA $^{q}$} \\
\hline Application timing $(\mathrm{T})$ & \multicolumn{2}{|c|}{ NS } & \multicolumn{2}{|c|}{ ** } & \multicolumn{2}{|c|}{$* *$} \\
\hline Herbicide $(\mathrm{H})$ & \multicolumn{2}{|c|}{$* *$} & \multicolumn{2}{|c|}{ ** } & \multicolumn{2}{|c|}{$* *$} \\
\hline $\mathrm{H} \times \mathrm{T}$ & \multicolumn{2}{|c|}{ ** } & \multicolumn{2}{|c|}{ NS } & \multicolumn{2}{|c|}{$*$} \\
\hline Rate (R) & \multicolumn{2}{|c|}{$* *$} & \multicolumn{2}{|c|}{$* *$} & \multicolumn{2}{|c|}{$* *$} \\
\hline $\mathrm{R} \times \mathrm{T}$ & \multicolumn{2}{|c|}{$* *$} & \multicolumn{2}{|c|}{$* *$} & \multicolumn{2}{|c|}{ NS } \\
\hline $\mathrm{R} \times \mathrm{H}$ & \multicolumn{2}{|c|}{$* *$} & \multicolumn{2}{|c|}{ NS } & \multicolumn{2}{|c|}{$* *$} \\
\hline $\mathrm{R} \times \mathrm{H} \times \mathrm{T}$ & \multicolumn{2}{|c|}{ NS } & \multicolumn{2}{|c|}{ NS } & \multicolumn{2}{|c|}{$*$} \\
\hline
\end{tabular}

zRates applied were $0,18,37,55$, and $74 \mathrm{~g} \cdot \mathrm{ha}^{-1}$ a.i. and $0,6,13,19$, and $26 \mathrm{~g} \cdot \mathrm{ha}^{-1}$ a.i. for BYS and SUL, respectively. Sulfosulfuron treatments include $0.25 \%$ nonionic surfactant.

${ }^{y}$ Cover transect ratings were recorded 4 weeks after application on 19 June 2007 and 25 June 2008.

${ }^{\mathrm{x}}$ Data were arcsine-transformed and means were averaged over four application timings, three replications per year, and 2 years. Back-transformed means are presented.

${ }^{\text {w} M e a n s ~ w i t h i n ~ a ~ c o l u m n ~ a n d ~ m a i n ~ e f f e c t ~ f o l l o w e d ~ b y ~ t h e ~ s a m e ~ l e t t e r ~ a r e ~ n o t ~ s i g n i f i c a n t l y ~ d i f f e r e n t ~ a t ~} P \leq$ 0.05 .

'Data were arcsine-transformed and means were averaged over four application timings and three replications per year. Back-transformed means are presented.

"Application timing means of CBG cover of the control plots were 84\%, 89\%, 92\%, and 94\% cover 7, 14, 21 , and $28 \mathrm{DAE}$, respectively, not different from each other $(\alpha=0.05)$. Application timing means of 2007 RSBG cover of the control plots were $71 \%, 82 \%, 92 \%$, and $97 \%$ cover $7,14,21$, and 28 DAE, respectively, not different from each other $(\alpha=0.05)$.

${ }^{t} \mathrm{DAE}=$ days after emergence (emergence $=50 \%$ cover of one to two leaf seedling).

sData were arcsine-transformed and means were averaged over five rates, three replications per year, and 2 years. Back-transformed means are presented.

${ }^{\mathrm{r}}$ Data were arcsine-transformed and means were averaged over five rates and three replications per year. Back-transformed means are presented.

${ }_{\mathrm{q}}^{\mathrm{NS}}, *, * *$ Nonsignificant, significant at $P \leq 0.05$, and significant at $P \leq 0.01$, respectively.

ANOVA $=$ analysis of variance. application timings (Table 2). Similarly, Dernoeden et al. (2008) demonstrated that when BYS was applied to 'Providence' CBG at 25 or $49 \mathrm{~g} \cdot \mathrm{ha}^{-1}$ a.i. 2 WAE, phytotoxicity remained within acceptable levels 2 WAT. We found that SUL applied at all tested rates caused more phytotoxicity than the control and means were lower than the acceptable level of 7.0 when rated 2 WAT (Table 2). Phytotoxicity of CBG averaged across herbicides decreased as applications were delayed after seeding with applications applied $28 \mathrm{~d}$ after emergence (DAE) being least injurious and 7 DAE applications being most injurious (data not shown). In practice, large areas of CBG would be undergoing renovation and likely be closed to traffic and golfer scrutiny. Therefore, chlorotic turf would not be considered objectionable unless thinning ultimately resulted. Although phytotoxicity is of concern, ultimately, cover reduction of CBG is most important to practitioners.

Averaged across application timings and years, BYS applied to seedling CBG at all but the $1.0 \times$ rate caused no reduction in cover when rated 4 WAT (Table 3). Furthermore, BYS applied on all application timings resulted in equivalent $\mathrm{CBG}$ cover rated 4 WAT when averaged across rates and years (Table 3 ). This display of CBG tolerance to BYS shortly after emergence may present an opportunity for early control of RSBG. Conversely, SUL applied at all tested rates reduced $\mathrm{CBG}$ cover $37 \%$ points or greater compared with the control when rated 4 WAT with cover decreasing with increasing rates (Table 3 ). Our previous research showed similar results with SUL applications reducing CBG seedling cover rated 8 weeks after seeding (Rutledge et al., 2009). In the same study, CBG phytotoxicity increased and cover decreased with applications made shortly after emergence and at higher rates. Similarly, in our current study, CBG mortality decreased with delayed SUL application after seeding. Averaged across rates, SUL
Table 4. Percent cover of spring-seeded roughstalk bluegrass 4 weeks after application of sulfosulfuron or bispyribac-sodium after emergence in 2007.

\begin{tabular}{lrrrr}
\hline & \multicolumn{4}{c}{ Application timing $\left(\mathrm{DAE}^{\mathrm{z}}\right)$} \\
\cline { 2 - 5 } Rate $^{\mathrm{y}}$ & 7 & \multicolumn{1}{c}{14} & 21 & 28 \\
\hline & $---------P e r c e n t$ & cover $^{\mathrm{x}}----------$ \\
0 & $86 \mathrm{a}^{\mathrm{wv}}$ & $92 \mathrm{a}$ & $83 \mathrm{a}$ & $87 \mathrm{a}$ \\
$0.25 \times$ & $11 \mathrm{~b}$ & $32 \mathrm{~b}$ & $13 \mathrm{~b}$ & $66 \mathrm{~b}$ \\
$0.5 \times$ & $7 \mathrm{~b}$ & $9 \mathrm{c}$ & $2 \mathrm{c}$ & $51 \mathrm{bc}$ \\
$0.75 \times$ & $1 \mathrm{c}$ & $2 \mathrm{~cd}$ & $2 \mathrm{c}$ & $41 \mathrm{c}$ \\
$1.0 \times$ & $0 \mathrm{c}$ & $0 \mathrm{~d}$ & $0 \mathrm{c}$ & $18 \mathrm{~d}$ \\
\hline
\end{tabular}

${ }^{2} \mathrm{DAE}=$ days after emergence (emergence $=50 \%$ cover of one to two leaf seedling).

${ }^{y}$ Rates applied were $0,18,37,55$, and $74 \mathrm{~g} \cdot \mathrm{ha}^{-1}$ a.i. and $0,6,13,19$, and $26 \mathrm{~g} \cdot \mathrm{ha}^{-1}$ a.i. for bispyribacsodium and sulfosulfuron, respectively.

${ }^{\mathrm{x}}$ Cover transect ratings were recorded 4 weeks after application on 19 June 2007.

wData were arcsine-transformed and means where averaged over three replications and two herbicides. Back-transformed means are presented.

${ }^{\mathrm{v}}$ Means within columns followed by the same letter are not significantly different at $P \leq 0.05$.
Table 5. Percent cover of spring-seeded roughstalk bluegrass 4 weeks after application of sulfosulfuron or bispyribac-sodium in 2008.

\begin{tabular}{llcccc}
\hline & & \multicolumn{4}{c}{ Application timing $\left(\mathrm{DAE}^{\mathrm{z}}\right)$} \\
\cline { 3 - 6 } Herbicide & Rate $^{\mathrm{y}}$ & 7 & \multicolumn{4}{c}{14} & 21 & 28 \\
\hline \multirow{2}{*}{ Sulfosulfuron } & 0 & $78 \mathrm{a}^{\mathrm{wv}}$ & $82 \mathrm{a}$ & $94 \mathrm{a}$ & $97 \mathrm{a}$ \\
& $0.25 \times$ & $0 \mathrm{~b}$ & $7 \mathrm{~b}$ & $17 \mathrm{~b}$ & $56 \mathrm{~b}$ \\
& $0.5 \times$ & $0 \mathrm{~b}$ & $2 \mathrm{~b}$ & $5 \mathrm{bc}$ & $49 \mathrm{~b}$ \\
& $0.75 \times$ & $0 \mathrm{~b}$ & $0 \mathrm{~b}$ & $2 \mathrm{bc}$ & $28 \mathrm{bc}$ \\
Bispyribac-sodium & $1.0 \times$ & $0 \mathrm{~b}$ & $0 \mathrm{~b}$ & $1 \mathrm{c}$ & $8 \mathrm{c}$ \\
& 0 & $63 \mathrm{a}$ & $83 \mathrm{a}$ & $88 \mathrm{a}$ & $96 \mathrm{a}$ \\
& $0.25 \times$ & $31 \mathrm{~b}$ & $59 \mathrm{a}$ & $85 \mathrm{a}$ & $83 \mathrm{ab}$ \\
& $0.5 \times$ & $3 \mathrm{c}$ & $28 \mathrm{~b}$ & $40 \mathrm{~b}$ & $83 \mathrm{ab}$ \\
& $0.75 \times$ & $0 \mathrm{c}$ & $22 \mathrm{bc}$ & $42 \mathrm{~b}$ & $73 \mathrm{~b}$ \\
& $1.0 \times$ & $0 \mathrm{c}$ & $5 \mathrm{c}$ & $20 \mathrm{~b}$ & $88 \mathrm{ab}$ \\
\hline
\end{tabular}

${ }^{\mathrm{z}} \mathrm{DAE}=$ days after emergence (emergence $=50 \%$ cover of one to two leaf seedling).

${ }^{y}$ Rates applied were $0,18,37,55$, and $74 \mathrm{~g} \cdot \mathrm{ha}^{-1}$ a.i. and $0,6,13,19$, and $26 \mathrm{~g} \cdot \mathrm{ha}^{-1}$ a.i. for bispyribac-sodium and sulfosulfuron, respectively. Sulfosulfuron treatments include $0.25 \%$ nonionic surfactant.

${ }^{\mathrm{x}}$ Cover transect ratings were recorded 4 weeks after application on 25 June 2008.

wData were arcsine-transformed and means were averaged over three replications. Back-transformed means are presented.

"Means within columns and herbicides followed by the same letter are not significantly different at $P \leq$ 0.05 . 
applied 28 DAE resulted in 86\% cover compared with $12 \%$ cover when applied 7 DAE (Table 3). Therefore, applications of SUL at the rates tested in this study would not be recommended until $28 \mathrm{DAE}$ for maximum CBG safety when seeded in spring. Although CBG maturity varied because of staggered seeding dates, there were no differences in cover among the control plots over the four seeding dates and thus comparisons between application timings were justified (Table 3 ).

Roughstalk bluegrass. Error variances between years were not homogeneous and thus data from years were analyzed and are presented separately in this study. Averaged across herbicides in 2007 , rates $0.5 \times$ or greater applied 7,14 , or $21 \mathrm{DAE}$ resulted in less than $10 \%$ RSBG cover, suggesting that exceptional RSBG control may be achieved when herbicides are applied within this range of rates and timings (Table 4). Also in 2007, SUL reduced RSBG cover to $5 \%$, less than BYS at $19 \%$ cover, when averaged across rates and application timings (data not shown). Sulfosulfuron applications in these studies generally resulted in less RSBG cover compared with when treated with BYS (Table 3). Single applications of SUL or BYS were used in these studies to

Table 6. Percent cover of fall-seeded creeping bentgrass 8 weeks after emergence influenced by sulfosulfuron (SUL) or bispyribac-sodium (BYS) in 2007.

\begin{tabular}{|c|c|c|}
\hline Main effect & SUL & BYS \\
\hline Rate $^{z}$ & \multicolumn{2}{|c|}{---Percent cover } \\
\hline 0 & $100 \mathrm{a}^{\mathrm{xw}}$ & $98 \mathrm{a}$ \\
\hline $0.25 x$ & $96 \mathrm{a}$ & $99 \mathrm{a}$ \\
\hline $0.5 \times$ & $81 \mathrm{~b}$ & $99 \mathrm{a}$ \\
\hline $0.75 x$ & $73 \mathrm{~b}$ & $99 \mathrm{a}$ \\
\hline $1.0 \times$ & $75 \mathrm{~b}$ & $96 \mathrm{a}$ \\
\hline \multicolumn{3}{|l|}{ Application timing } \\
\hline $7 \mathrm{DAE}^{\mathrm{v}}$ & $66 b^{u}$ & $98 \mathrm{a}$ \\
\hline 14 DAE & $90 \mathrm{a}$ & $96 \mathrm{a}$ \\
\hline $21 \mathrm{DAE}$ & $91 \mathrm{a}$ & $99 \mathrm{a}$ \\
\hline 28 DAE & $97 \mathrm{a}$ & $99 \mathrm{a}$ \\
\hline \multicolumn{3}{|l|}{ ANOVA $^{t}$} \\
\hline Application timing (T) & \multicolumn{2}{|l|}{ * } \\
\hline Herbicide (H) & \multicolumn{2}{|c|}{ ** } \\
\hline $\mathrm{H} \times \mathrm{T}$ & \multicolumn{2}{|c|}{$* *$} \\
\hline Rate $(\mathrm{R})$ & \multicolumn{2}{|c|}{$* *$} \\
\hline $\mathrm{R} \times \mathrm{T}$ & \multirow{2}{*}{\multicolumn{2}{|c|}{$\begin{array}{c}* \\
* *\end{array}$}} \\
\hline $\mathrm{R} \times \mathrm{H}$ & & \\
\hline $\mathrm{R} \times \mathrm{H} \times \mathrm{T}$ & \multicolumn{2}{|c|}{ NS } \\
\hline
\end{tabular}

${ }^{\mathrm{z}}$ Rates applied were $0,18,37,55$, and $74 \mathrm{~g} \cdot \mathrm{ha}^{-1}$ a.i. and $0,6,13,19$, and $26 \mathrm{~g} \cdot \mathrm{ha}^{-1}$ a.i. for BYS and SUL, respectively. Sulfosulfuron treatments include $0.25 \%$ nonionic surfactant.

${ }^{y}$ Cover transect ratings were recorded 8 weeks after emergence on 10 Oct. 2007.

${ }^{x}$ Data were arcsine-transformed and means were averaged across four application timings and three replications. Back-transformed means are presented. "Means within a column and main effect followed by the same letter are not significantly different at $P \leq 0.05$.

${ }^{ } \mathrm{DAE}=$ days after emergence $($ emergence $=50 \%$ cover of one to two leaf seedling).

"Data were arcsine-transformed and means were averaged across five rates and three replications. Back-transformed means are presented.

${ }^{\mathrm{t}} \mathrm{NS}, *, * *$ Nonsignificant, significant at $P \leq 0.05$, and significant at $P \leq 0.01$, respectively.

ANOVA $=$ analysis of variance. identify when CBG tolerance was enough to justify application. However, Morton et al. (2007) applied multiple applications of SUL or BYS at high label rates on mature turf and found SUL and BYS performed equally. Additionally, preliminary data from adjacent studies indicate sequential applications of BYS or SUL improve their efficacy on RSBG but do not decrease safety on CBG (Rutledge and Reicher, 2008).

In 2008, SUL applied at any tested rate 7, 14,21 , or 28 DAE reduced RSBG cover compared with the control (Table 5). RSBG cover was reduced to $7 \%$ cover or less when SUL was applied 7 or 14 DAE at any tested rate (Table 5). When applied 21 or $28 \mathrm{DAE}$, SUL was most effective at $0.5 \times$ or greater or $0.75 \times$ or greater, respectively. Sulfosulfuron applied $28 \mathrm{DAE}$ at $1.0 \times$ reduced RSBG cover to $8 \%$, whereas BYS applied 28 DAE at $1.0 \times$ only reduced RSBG cover to $88 \%$, demonstrating the greater effectiveness of SUL when applied later than BYS (Table 5). Bispyribac-sodium was most effective when applied $7 \mathrm{DAE}$ at rates of $0.5 \times$ or greater, reducing RSBG cover to $3 \%$ or less (Table 5). Similar to SUL, control from BYS waned because application was delayed after seeding. By 28 DAE, only BYS applied at $0.75 \times$ resulted in RSBG cover less than the control (Table 5).

\section{Fall studies}

Creeping bentgrass. Error variances between years were not homogeneous and thus years were analyzed and are presented separately in this study. Similar to spring-seeded studies, phytotoxicity was short-lived and had dissipated by 3 weeks after application across all treatments (data not shown). Like in spring-seeded studies, SUL was more damaging to CBG than BYS. Sulfosulfuron applied at $0.25 \times$ resulted in more $\mathrm{CBG}$ cover than higher rates $8 \mathrm{WAE}$ in 2007 when averaged across application timings (Table 6). Unlike the spring-seeded study, SUL at $0.25 \times$ caused no reduction in CBG cover compared with the control, which may partially result from 7 weeks of recovery in fall compared with only 4 weeks of recovery in spring. Data reported in fall-seeded studies was recorded $8 \mathrm{WAE}$, which was $7,6,5$, or 4 weeks after herbicide application 7, 14, 21, or 28 DAE, respectively (Table 1). Averaged across rates in 2007, SUL applied 14, 21, or $28 \mathrm{DAE}$ resulted in $24 \%$ points or greater more CBG cover than when applied 7 DAE (Table 6). Conversely, BYS did not reduce CBG cover regardless of rate or application timing (Table 6). These results were further confirmed in 2008 when SUL applied 7 DAE at rates greater than $0.25 \times$ resulted in greater than $53 \%$ points less CBG cover than the control (Table 7). When applied 21 DAE, SUL at any rate caused no reduction in CBG cover compared with the control. Like in 2007, BYS applied at any application timing or rate resulted in CBG cover equal to that of the untreated control in 2008 (Table 7). Sulfosulfuron applied at any tested rate 28 DAE generally resulted in less CBG cover than when applied 21 DAE in 2008, especially at the $1.0 \times$ rate (Table 7 ). This was partially the result of only 4 weeks of recovery for $28 \mathrm{DAE}$ treatments compared with 5 weeks of recovery for the 21 DAE

Table 7. Percent cover of fall-seeded creeping bentgrass 8 weeks after emergence influenced by sulfosulfuron or bispyribac-sodium in 2008.

\begin{tabular}{|c|c|c|c|c|c|}
\hline \multirow[b]{2}{*}{ Herbicide } & \multirow[b]{2}{*}{ Rate $^{\mathrm{y}}$} & \multicolumn{4}{|c|}{ Application timing (DAE $\left.{ }^{z}\right)$} \\
\hline & & 7 & 14 & 21 & 28 \\
\hline & & ---------- & $--\mathrm{Pe}$ & rix----- & ------- \\
\hline \multirow[t]{5}{*}{ Sulfosulfuron } & 0 & $96 \mathrm{a}^{\mathrm{wv}}$ & $96 \mathrm{a}$ & $95 \mathrm{a}$ & $93 \mathrm{a}$ \\
\hline & $0.25 \times$ & $93 \mathrm{a}$ & $98 \mathrm{a}$ & $94 \mathrm{a}$ & $90 \mathrm{a}$ \\
\hline & $0.5 \times$ & $42 \mathrm{~b}$ & $92 \mathrm{a}$ & $94 \mathrm{a}$ & $86 \mathrm{ab}$ \\
\hline & $0.75 \times$ & $10 \mathrm{c}$ & $91 \mathrm{a}$ & $94 \mathrm{a}$ & $81 \mathrm{ab}$ \\
\hline & $1.0 \times$ & $0 \mathrm{~d}$ & $57 \mathrm{~b}$ & $91 \mathrm{a}$ & $62 \mathrm{~b}$ \\
\hline \multirow[t]{5}{*}{ Bispyribac-sodium } & 0 & $98 \mathrm{a}$ & $97 \mathrm{a}$ & $95 \mathrm{a}$ & $95 \mathrm{a}$ \\
\hline & $0.25 \times$ & $98 \mathrm{a}$ & $98 \mathrm{a}$ & $96 \mathrm{a}$ & $94 \mathrm{a}$ \\
\hline & $0.5 \times$ & $100 \mathrm{a}$ & $98 \mathrm{a}$ & $94 \mathrm{a}$ & $96 \mathrm{a}$ \\
\hline & $0.75 \times$ & $98 \mathrm{a}$ & $97 \mathrm{a}$ & 89 a & $97 \mathrm{a}$ \\
\hline & $1.0 \times$ & $96 \mathrm{a}$ & $98 \mathrm{a}$ & $94 \mathrm{a}$ & 94 a \\
\hline \multicolumn{6}{|l|}{ ANOVA $^{u}$} \\
\hline Application timing (T) & & $* *$ & & & \\
\hline Herbicide $(\mathrm{H})$ & & $* *$ & & & \\
\hline $\mathrm{H} \times \mathrm{T}$ & & $* *$ & & & \\
\hline Rate (R) & & $* *$ & & & \\
\hline $\mathrm{R} \times \mathrm{T}$ & & $* *$ & & & \\
\hline $\mathrm{R} \times \mathrm{H}$ & & $* *$ & & & \\
\hline $\mathrm{R} \times \mathrm{H} \times \mathrm{T}$ & & $* *$ & & & \\
\hline
\end{tabular}

${ }^{\mathrm{z}} \mathrm{DAE}=$ days after emergence (emergence $=50 \%$ cover of one to two leaf seedling).

${ }^{y}$ Rates applied were $0,18,37,55$, and $74 \mathrm{~g} \cdot \mathrm{ha}^{-1}$ a.i. and $0,6,13,19$, and $26 \mathrm{~g} \cdot \mathrm{ha}^{-1}$ a.i. for bispyribac-sodium and sulfosulfuron, respectively. Sulfosulfuron treatments include $0.25 \%$ nonionic surfactant.

${ }^{\mathrm{x}}$ Cover transect ratings were recorded 8 weeks after emergence on 21 Oct. 2008.

${ }^{\text {w}}$ Data were arcsine-transformed and means were averaged over three replications. Back-transformed means are presented.

${ }^{v}$ Means within a column and main effect followed by the same letter are not significantly different at $P \leq$ 0.05 .

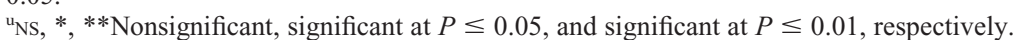

ANOVA $=$ analysis of variance. 
Table 8. Percent cover of fall-seeded roughstalk bluegrass 8 weeks after emergence influenced by sulfosulfuron or bispyribac-sodium across 2007 and 2008.

\begin{tabular}{lc}
\hline Main effect & \\
\hline Herbicide & Percent cover \\
Sulfosulfuron (SUL) & $46 \mathrm{~b}^{\mathrm{yx}}$ \\
Bispyribac-sodium (BYS) $^{\mathrm{x}}$ & $68 \mathrm{a}$ \\
Rate $^{\mathrm{w}}$ & \\
0 & $95 \mathrm{a}^{\mathrm{v}}$ \\
$0.25 \times$ & $75 \mathrm{~b}$ \\
$0.5 \times$ & $46 \mathrm{c}$ \\
$0.75 \times$ & $36 \mathrm{~cd}$ \\
$1.0 \times$ & $24 \mathrm{~d}$ \\
ANOVA & \\
Application timing (T) & $\mathrm{NS}$ \\
Herbicide $(\mathrm{H})$ & $* *$ \\
$\mathrm{H} \times \mathrm{T}$ & $\mathrm{NS}$ \\
Rate $(\mathrm{R})$ & $* *$ \\
$\mathrm{R} \times \mathrm{T}$ & $\mathrm{NS}$ \\
$\mathrm{R} \times \mathrm{H}$ & $\mathrm{NS}$ \\
$\mathrm{R} \times \mathrm{H} \times \mathrm{T}$ & $\mathrm{NS}$ \\
\hline
\end{tabular}

${ }^{{ }^{z} \text { Cover transect ratings were recorded } 8 \text { weeks after }}$ emergence on 10 Oct. 2007 and 21 Oct. 2008.

${ }^{y}$ Data were arcsine-transformed and means were average across four application timings, five rates, three replications per year, and 2 years. Backtransformed means are presented.

${ }^{\mathrm{x}}$ Means within a column and main effect followed by the same letter are not significantly different at $P \leq 0.05$.

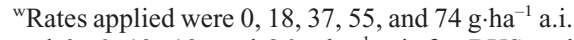
and $0,6,13,19$, and $26 \mathrm{~g} \cdot \mathrm{ha}^{-1}$ a.i. for BYS and SUL, respectively.

${ }^{\vee}$ Data were arcsine-transformed and means were average across four application timings, two herbicides, three replications per year, and 2 years. Back-transformed means are presented.

${ }^{u_{N S}, *}, * *$ Nonsignificant, significant at $P \leq 0.05$, and significant at $P \leq 0.01$, respectively.

ANOVA $=$ analysis of variance.

treatments. Additionally, a rapid temperature decline immediately after herbicide application in 2008 resulted in increased CBG mortality (Fig. 1). These results confirm the importance of applying SUL or BYS during warm temperatures as concluded by McCullough and Hart (2006a, 2006b, 2008).

Roughstalk bluegrass. Error variances between years were homogenous and thus years were combined in the statistical analysis of this study. Only main effects of herbicide and rate were significant for fall-seeded RSBG. Like in spring-seeded studies, SUL reduced RSBG cover more than BYS (Table 8). Averaged across application timings and herbicides, all herbicide rates in the study reduced RSBG cover compared with the control 8 WAE (Table 8). Averaged across application timings and herbicides, the $0.25 \times$ rate resulted in $75 \%$ RSBG cover, whereas the $0.5 \times, 0.75 \times$, and $1.0 \times$ rates reduced RSBG to $46 \%, 36 \%$, and $24 \%$ cover 8 WAE, respectively (Table 8 ).
Application timing was not significant and thus equivalent RSBG control was achieved applying SUL or BYS 28 DAE to minimize risk of reducing $\mathrm{CBG}$ cover, although minimal gains in control were observed when herbicides were applied closer to emergence (Table 8).

\section{Conclusions}

Our data show that BYS may be applied to spring-seeded CBG as early as 7 DAE at rates up to $55 \mathrm{~g} \cdot \mathrm{ha}^{-1}$ a.i. Although safety increases minimally with lower rates and longer delays after emergence, RSBG control from BYS is most effective at rates $37 \mathrm{~g} \cdot \mathrm{ha}^{-1}$ a.i. or greater when applied 7 or 14 DAE. As mentioned earlier, preliminary work suggests sequential applications of BYS can improve RSBG control with limited risk to CBG (Rutledge and Reicher, 2008). Conversely, SUL was safest to spring-seeded CBG when applied $28 \mathrm{DAE}$, but all tested rates were damaging. Although SUL was more effective than BYS in controlling seedling BSBG in a spring seeding, safety to $\mathrm{CBG}$ was unacceptable in our current study.

Fall-seeded CBG was generally less sensitive to BYS and SUL applications and thus recommendations are less conservative than in the spring-seeded studies. However, CBG remained more sensitive to SUL compared with BYS at rates tested in these studies. Sulfosulfuron should not be applied to fall-seeded CBG before $14 \mathrm{DAE}$ at rates above $6 \mathrm{~g} \cdot \mathrm{ha}^{-1}$ a.i. and should not be applied before $21 \mathrm{DAE}$ at rates above $19 \mathrm{~g} \cdot \mathrm{ha}^{-1}$ a.i. Similar to spring-seeded studies, BYS may be applied as soon as 7 DAE at rates $74 \mathrm{~g} \cdot \mathrm{ha}^{-1}$ a.i. or less. Roughstalk bluegrass control was not dependent on application timing and thus SUL or BYS can be applied 28 DAE to minimize CBG cover loss.

\section{Literature Cited}

Anonymous. 2004. Velocity product label. Valent U.S.A. Corp., Walnut Creek, CA.

Anonymous. 2005. Certainty product label. Monsanto Company, St. Louis, MO.

Askew, S.D., J.B. Beam, D.S. McCall, W.L. Barker, H.B. Couch, and J.R. Chamberlin. 2004. Annual bluegrass, roughstalk bluegrass, and dollar spot control with bispyribac-sodium. Proc. Northeast Weed Sci. Soc. 58:124-126.

Dernoeden, P.H., S.J. McDonald, and J.E. Kaminski. 2008. Creeping bentgrass and perennial ryegrass seedling tolerance to bispyribac-sodium. HortScience 43:2186-2190.

Grime, J.P., G. Mason, A.V. Curtis, J. Rodman, S.R. Band, M.S.G. Mowforth, A.M. Neal, S. Shaw, and T. Pearce. 1981. A comparative study of germination characteristics in a local flora. J. Ecol. 69:1017-1059.

Hurley, R.H. 1983. Rough bluegrass: Genetic variability, disease susceptibility and response to shade. PhD diss, Rutgers University, New Brunswick, NJ.

Hurley, R.H. and C.R. Funk. 1985. Genetic variability in disease reaction, turf quality, leaf color, leaf texture, plant density, and seed shattering of selected genotypes of Poa trivialis. Int. Turfgrass Soc. Res. J. 14:221-226.

Levy, M. 1998. Poa trivialis contamination: An increase in testing standards would benefit superintendents. USGA Green Sec. Rec. 36: 13-14.

McCullough, P.E. and S.E. Hart. 2006a. Temperature influences creeping bentgrass (Agrostis stolonifera) and annual bluegrass (Poa annua) response to bispyribac-sodium. Weed Technol. 20:728-732.

McCullough, P.E. and S.E. Hart. 2006b. Temperature influences efficacy of bispyribac-sodium, primisulfuron, and sulfosulfuron. Proc. 15th Annual Rutgers Turfgrass Symposium. 40 (abstr.).

McCullough, P.E. and S.E. Hart. 2008. Creeping bentgrass (Agrostis stolonifera) tolerance to sulfosulfuron. Weed Technol. 22:481-485.

Milton, W.E.J. 1936. The buried viable seeds of enclosed and unenclosed hill land. Rep. Welsh Pl. Breed Stn., Series H 14:58-84.

Morton, D., D. Weisenberger, Z. Reicher, B. Branham, B. Sharp, R. Gaussoin, J. Stier, and E. Koeritz. 2007. Evaluating bispyribac-sodium and sulfosulfuron for control of roughstalk bluegrass. HortScience 42:1710-1714.

Morton, D.E., D.V. Weisenberger, and Z.J. Reicher. 2009. Response of eight cultivars of roughstalk bluegrass to bispyribac or sulfosulfuron. Online. Appl Turfgrass Sci 10.1094/ ATS-2009-0831-01-RS.

Mueller-Warrant, G.W. 1990. Control of roughstalk bluegrass (Poa trivialis) with fenoxaprop in perennial ryegrass (Lolium perenne) grown for seed. Weed Technol. 4:250-257.

Mueller-Warrant, G.W. and S.C. Rosato. 2005. Weed control for tall fescue seed production and stand duration without burning. Crop Sci. 45:2614-2628.

Riego, D.C., D.H. Williamson, and J.C. Graham. 2005. Roughstalk bluegrass control in creeping bentgrass with MON 44951 75WDG in midwest and northeast U.S. Proc. Northeast Weed Sci. Soc. 58:88.

Rutledge, J.M. and Z.J. Reicher. 2008. Two applications of Certainty or Velocity to control seedling Poa trivialis in seedling creeping bentgrass. 2008 Purdue turfgrass research summary. 6 Aug. 2009. <http://www.agry.purdue. edu/turf/report/2008/PDF/514.pdf>.

Rutledge, J.M., D.V. Weisenberger, and Z.J. Reicher. 2009. Effect of sulfosulfuron on 'Penncross' creeping bentgrass seedlings when applied before or after seeding. Online. Appl. Turfgrass Sci. 10.1094/ATS-2009-0710-01-RS.

Sifers, S.I. and J.B. Beard. 1993. Comparative inter- and intra-specific leaf firing resistance to supraoptimal air and soil temps in coolseason turfgrass genotypes. International Turfgrass Society Research Journal. 7:621-628.

Steel, R.G.D., J.H. Torrie, and D.A. Dickey. 1997. Principles and procedures of statistics a biometrical approach. 3rd Ed. McGraw-Hill Book Co., New York, NY. 